\title{
Purification and characterization of a hyaluronidase from venom of the spider Vitalius dubius (Araneae, Theraphosidae)
}

\author{
Rafael Sutti ${ }^{1}$, Mariana Leite Tamascia ${ }^{2}$, Stephen Hyslop ${ }^{2}$ and Thomaz Augusto Alves Rocha-e-Silva ${ }^{1 *}$
}

\begin{abstract}
Background: Venom hyaluronidase (Hyase) contributes to the diffusion of venom from the inoculation site. In this work, we purified and characterized Hyase from the venom of Vitalius dubius (Araneae, Theraphosidae), a large theraphosid found in southeastern Brazil. Venom obtained by electrical stimulation of adult male and female $V$. dubius was initially fractionated by gel filtration on a Superdex ${ }^{\circledR} 75$ column. Active fractions were pooled and applied to a heparin-sepharose affinity column. The proteins were eluted with a linear $\mathrm{NaCl}$ gradient.
\end{abstract}

Results: Active fractions were pooled and assessed for purity by SDS-PAGE and RP-HPLC. The physicochemical tests included optimum pH, heat stability, presence of isoforms, neutralization by flavonoids and assessment of commercial antivenoms. Hyase was purified and presented a specific activity of 148 turbidity-reducing units (TRU)/mg (venom: 36 TRU/mg; purification factor of 4). Hyase displayed a molecular mass of $43 \mathrm{kDa}$ by SDS-PAGE. Zymography in hyaluronic-acid-containing gels indicated an absence of enzyme isoforms. The optimum pH was 4-5, with highest activity at $37^{\circ} \mathrm{C}$. Hyase was stable up to $60^{\circ} \mathrm{C}$; but its activity was lost at higher temperatures and maintained after several freeze-thaw cycles. The $\mathrm{NaCl}$ concentration (up to $1 \mathrm{M}$ ) did not influence activity. Hyase had greater action towards hyaluronic acid compared to chondroitin sulfate, and was completely neutralized by polyvalent antiarachnid sera, but not by caterpillar, scorpion or snakes antivenoms.

Conclusion: The neutralization by arachnid but not scorpion antivenom indicates that this enzyme shares antigenic epitopes with similar enzymes in other spider venoms. The biochemical properties of this Hyase are comparable to others described.

Keywords: Hyaluronidase, Venom, Purification, Vitalius dubius

\section{Background}

Spider venoms comprise complex mixtures of components of low molecular weight, peptides and proteins [1]. Among the enzymatic activities, collagenase and hyaluronidase (Hyase) are often found and were formerly attributed to matrix degradation [1].

Hyase activity is found in several spider species, such as Cupiennius salei, Lycosa godeffroy, Lampona cylindrata/murina, Loxosceles recluse, Loxosceles rufescens, Loxosceles deserta, Loxosceles gaucho, Loxosceles laeta, Loxosceles recluse, and Loxosceles intermedia [1-6]. The

\footnotetext{
* Correspondence: thomaz.silva@fcmsantacasasp.edu.br

'Department of Physiological Sciences, Santa Casa de São Paulo Medical School, Rua Cesário Motta Jr., 61, Vila Buarque, CEP 01.221-020 São Paulo, SP, Brasil

Full list of author information is available at the end of the article
}

first report of hyaluronidasic activity was in venoms of the Brazilian spiders Lycosa raptorial and Phoneutria nigriventer $[7,8]$. The first Hyase to be purified from a Theraphosidae spider was the one from the tarantula Dugesiella hentzi (Girard), which was characterized and identified as the major venom component [9].

The clinical relevance of Hyases is not confined to a toxin-spreading factor, since it acts as an allergen in a manner similar to hymenoptera venoms. Hyase, phospholipase A2 and melitin were identified as the tree major causes of allergic reactions involved in bee stings, and phospholipase A1 and antigen 5 are the major allergens in wasp venoms $[10,11]$.

Although tarantula bites to humans are relatively rare [12-14], these spider venoms represent a rich source of

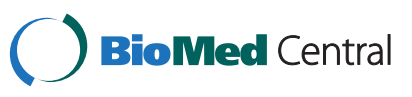

(c) 2014 Sutti et al.; licensee BioMed Central Ltd. This is an open access article distributed under the terms of the Creative Commons Attribution License (http://creativecommons.org/licenses/by/2.0), which permits unrestricted use, distribution, and reproduction in any medium, provided the original work is properly cited. 
bioactive molecules for scientific interest, basic research and possible therapeutic applications [15-18].

The tarantula Vitalius dubius (Mello-Leitão, 1923) is characterized as nonaggressive and is found in the very populous area of southeastern Brazil [19]. Recent studies have shown that $V$. dubius venom has a complex biochemical and pharmacological composition, with different biological activities [20,21]. In the present work we describe the purification and characterization of the hyaluronidase present in its venom.

\section{Methods}

\section{Reagents}

Refined chemicals were purchased from Sigma Chemical Co. (USA) whereas heparin was purchased from Laboratório Cristália (Brazil). Molecular mass markers for SDSPAGE were acquired from BioRad (USA). The resins for column chromatography were purchased from GE Healthcare Life Sciences (Sweden). The HPLC column was a Jupiter C18 $(4.6 \mathrm{~mm} \times 250 \mathrm{~mm} \times 12 \mu \mathrm{m})$ acquired from Phenomenex (USA).

\section{Spiders and venom extraction}

Specimens of $V$. dubius and Phoneutria nigriventer were provided by the Centers for Zoonosis Control for the cities in the region of Campinas, São Paulo state. The spiders were identified and kept in captivity, where they were fed cockroaches and water ad libitum. The tarantula venom was extracted as described by Rocha-e-Silva et al. [20] then lyophilized and stored at $-80^{\circ} \mathrm{C}$ until use.

\section{Antisera}

We used six antivenom sera produced by the Butantan Institute in São Paulo: (1) antiarachnid (Phoneutria nigriventer, Loxosceles gaucho and Tityus serrulatus); (2) antiscorpionic (T. serrulatus); (3) antilonomic (Lonomia obliqua); (4) antibothropic (Bothrops alternatus, B. jararaca, B. jararacussu, B. moojeni and B. neuwiedi); (5) anticrotalic (Crotalus durissus terrificus and Crotalus durissus collilineatus); and (6) antielapidic (Micrurus frontalis and M. corallinus).

\section{Enzymatic activity}

Hyaluronidase activity was determined by a turbidimetric method [22]. The working solution for this trial consisted of a $200 \mu \mathrm{L}$ buffer $(0.2 \mathrm{M}$ sodium acetate, $\mathrm{pH}$ 6.0, containing $0.15 \mathrm{M} \mathrm{NaCl}$ ), $200 \mu \mathrm{L}$ of substrate (hyaluronic acid from human umbilical cord $1 \mathrm{mg} / \mathrm{mL}$ in acetate buffer) and $100 \mu \mathrm{L}$ of enzyme $(20 \mu \mathrm{g})$ to give a total reaction volume of $500 \mu \mathrm{L}$. This mixture was incubated for 15 minutes at $37^{\circ} \mathrm{C}$ after which the reaction was stopped by adding $2 \mathrm{~mL}$ of hexadecyltrimethylammonium bromide in $2.5 \% \mathrm{NaOH}$. The resulting turbidity was read at $400 \mathrm{~nm}$ in a SpectraMax 340 microplate reader (Molecular Devices, USA) after 30 minutes of incubation at room temperature. One unit of activity corresponded to the amount of enzyme that produced a $50 \%$ reduction in turbidity caused by $200 \mu \mathrm{g}$ of substrate under the conditions described above.

\section{Purification of Hyaluronidase}

The venom (10 mg) of $V$. dubius was dissolved in $0.1 \mathrm{M}$ sodium acetate buffer, $\mathrm{pH} 6.0$, containing $0.15 \mathrm{M} \mathrm{NaCl}$, and fractionated by a Superdex ${ }^{\circ} 75$ gel filtration column $(10 \mathrm{~mm} \times 30 \mathrm{~cm})$ balanced and eluted with the same buffer. Fractions of $1.5 \mathrm{~mL}$ each were collected at a flow rate of $1 \mathrm{~mL}$ per minute using an ÄKTA-Purifier chromatographic system (Pharmacia, Sweden). The elution profile was determined by monitoring the absorbance at $280 \mathrm{~nm}$.

The hyaluronidase-containing fractions eluted from the previous step were applied to a heparin-sepharose column equilibrated with $0.1 \mathrm{M}$ sodium acetate buffer, $\mathrm{pH}$ 6.0. The fractions were washed and eluted under a gradient of $\mathrm{NaCl}(0$ to $1.0 \mathrm{M})$. The elution profile was determined by monitoring the absorbance at $280 \mathrm{~nm}$ whereas fractions $(1.5 \mathrm{~mL})$ containing the enzyme were stored at $8^{\circ} \mathrm{C}$.

Hyase purity was evaluated by RP-HPLC chromatography using a resource RPC column $(4.6 \mathrm{~mm} \times 250 \mathrm{~mm} \times$ $12 \mu \mathrm{m})$. The column was balanced with $0.1 \%$ trifluoracetic acid (TFA) and the enzyme was eluted with a linear gradient $(0-100 \%)$ of $66 \%$ acetonitrile in $0.1 \%$ TFA. The elution profile was monitored at $280 \mathrm{~nm}$.

\section{SDS-polyacrylamide gel electrophoresis (SDS-PAGE) and zymography}

Electrophoresis was performed using $12 \%$ acrylamide or 5-20\% gradients gels [23]. The existence of isoforms of

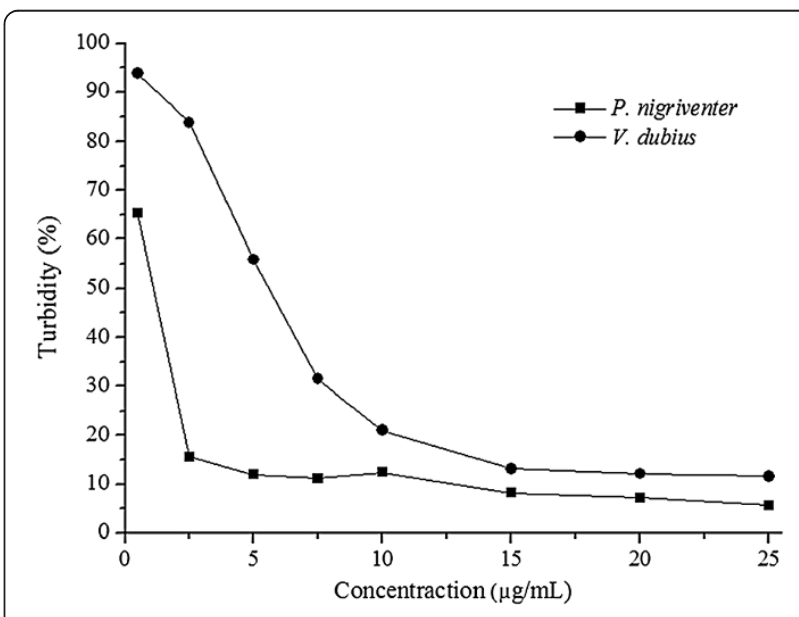

Figure 1 Comparison of hyaluronidase activity present in the venom of $\boldsymbol{V}$. dubius and $P$. nigriventer. The values represent the mean \pm S.E. $(n=6)$. 


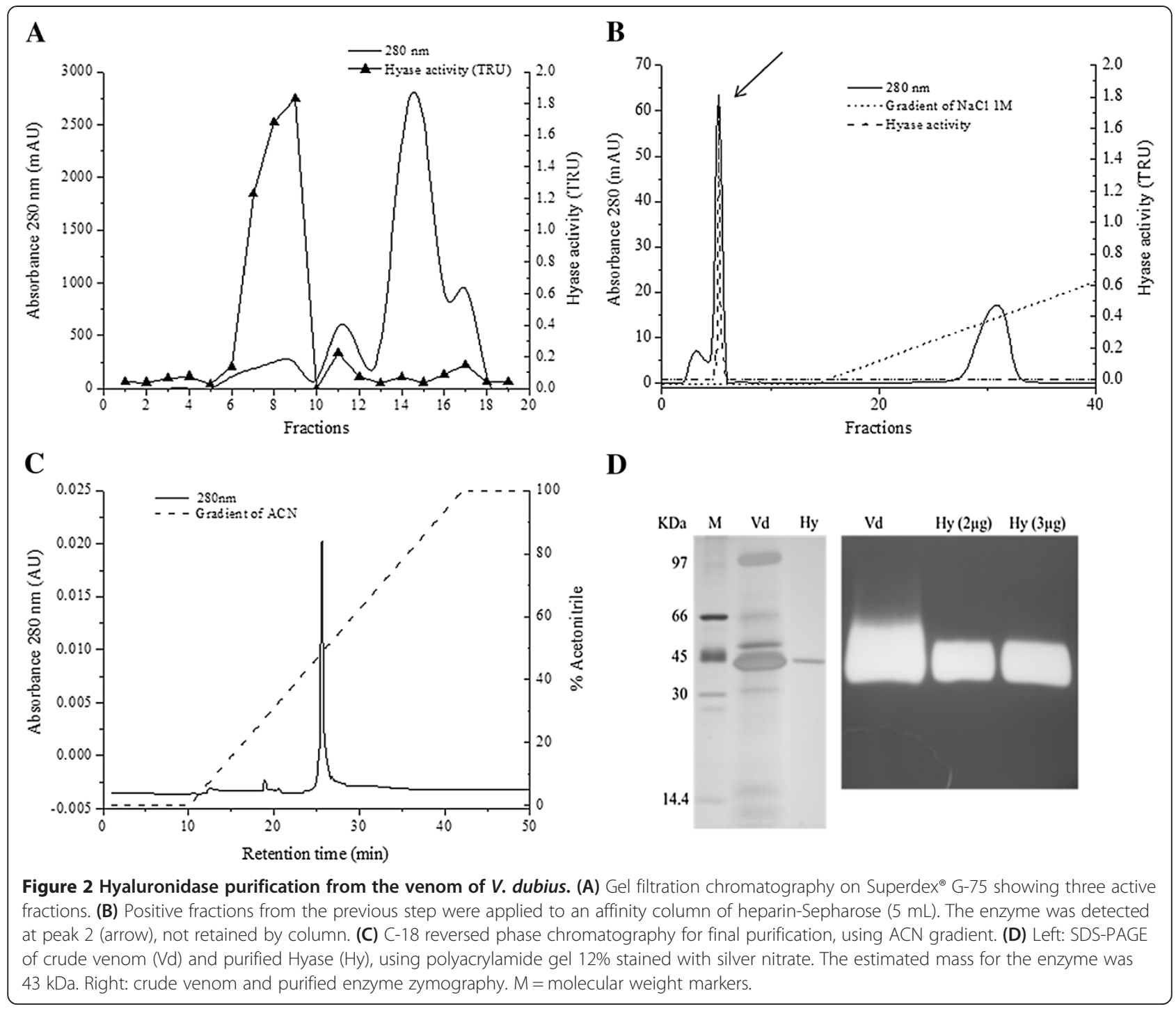

Hyase was investigated as described by Cevallos et al. [24]. The hyaluronic acid was mixed into the SDSpolyacrylamide gels to obtain a final concentration of $0.6 \mathrm{mg} / \mathrm{mL}$ of non-polymerized solution.

During zymography, the electrophoretic separation phase was performed under the same conditions previously described (gels, buffers etc.), except for the samples, that were not warmed, to conserve their enzymatic activities. After Stains all staining (Sigma-Aldrich Co.), the gel was washed with a buffer containing $0.015 \mathrm{M}$ Tris- $\mathrm{HCl}, 5 \%$ formamide and 20\% isopropyl alcohol, $\mathrm{pH} 7.9$, and photo documented.

\section{Physicochemical characterization of the enzyme}

The optimum $\mathrm{pH}$ was determined by changing the buffers of the enzymatic turbidimetric assay as follows: $0.1 \mathrm{M}$ sodium citrate, $\mathrm{pH} 3.0$ to $6.0,0.1 \mathrm{M}$ sodium acetate, $\mathrm{pH} 4.0$ to 6.0 and $0.1 \mathrm{M}$ Tris- $\mathrm{HCl}, \mathrm{pH} 5.5$ to 8.0 $(0.15 \mathrm{M} \mathrm{NaCl}$ was added to all buffers).
The optimal working temperature of the enzyme was evaluated by adjusting assay temperature between 10 and $70^{\circ} \mathrm{C}$. The thermal stability of the enzyme was tested by pre-incubating enzyme solution for 15 minutes under a temperature ranging from 25 to $80^{\circ} \mathrm{C}$.

To evaluate freezing longevity of the enzyme, separated aliquots were stored at $-20^{\circ} \mathrm{C}$ and enzyme activity measured at the times 1, 2, 3, 6, 24, 72 hours and 7 and 15 days. Each aliquot was thawed once before the assay. To evaluate freezing cycles stability, a stock solution was stored, then thawed and refrozen for each enzyme assay, following same intervals in the freezing longevity test.

We investigated substrate specificity of the enzyme towards hyaluronic acid and chondroitin sulfate A. For this assay the Hyase activity was measured by quantifying the released sugars according to the colorimetric method of Reissig et al. [25]. 
The maximum reaction velocity $\left(\mathrm{V}_{\max }\right)$ and the substrate concentration that results in the half of the maximum velocity $\left(K_{m}\right)$ were assessed with fixed amounts of enzyme and variable substrate concentrations. The $\mathrm{N}$-acetylamine release was quantified by the method of Reissig et al. [25]. The parameters were calculated using Lineweaver-Burk graphs, as previously described by Segel [26].

\section{Immunological comparisons}

An ELISA test was used to assess cross-reactivity between the enzyme and the commercial sera against several venomous species of spiders, scorpions and snakes.

The ability of Instituto Butantan's commercial antivenom to neutralize the enzymatic activity of $V$. dubius was assessed using the turbidimetric assay. The enzyme was pre-incubated with different volumes of each antivenom for 30 minutes at $37^{\circ} \mathrm{C}$ before measuring the enzyme activity. Control assays were performed using venom only.

\section{Statistics}

The results were expressed as the mean \pm SEM for the number of assays. Statistical comparisons were made using ANOVA followed by the Tukey test, with $\mathrm{p}<0.05$ indicating significance.

\section{Results}

The Hyase activity of $V$. dubius venom was lower than that of $P$. nigriventer (with respective turbidities of 11.6 and 5.6\%). The venom of $P$. nigriventer reached assay saturation at a concentration of $5 \mu \mathrm{g} / \mathrm{mL}$, while $V$. dubius venom showed maximum activity at $15 \mu \mathrm{g} / \mathrm{mL}$ (Figure 1 ).

Hyase purification was initiated through a size exclusion chromatography, which provided three active

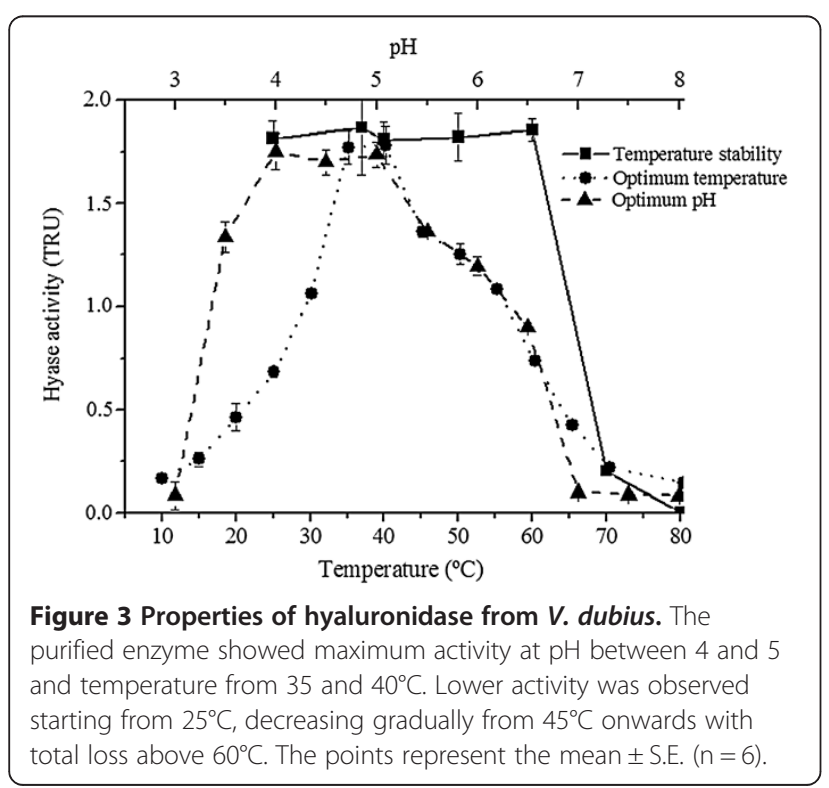

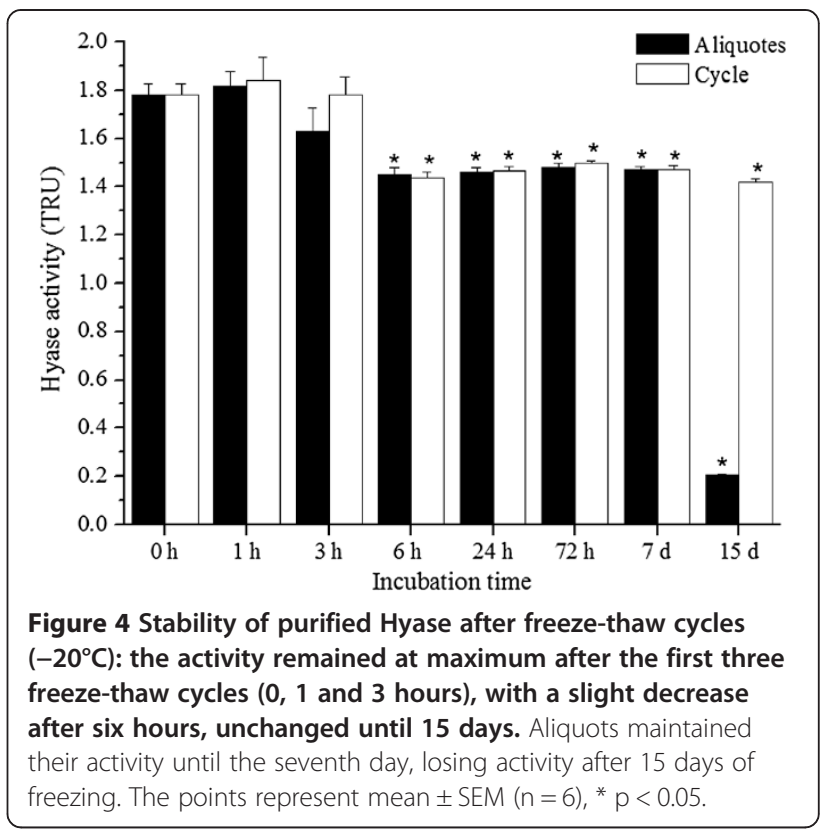

fractions (fractions 7, 8 and 9), pooled for the second stage (Figure 2A). In the following affinity chromatography, Hyase activity was detected in one fraction (Figure 2B) (fraction 5). Reversed-phase HPLC provided the purified Hyase (Figure $2 \mathrm{C}$ ). The enzyme purity was confirmed by a $12 \%$ SDS-PAGE and zymography, which showed only one band around $43 \mathrm{kDa}$ (Figure 2D).

About $850 \mu \mathrm{g}$ of purified Hyase was obtained from $18 \mathrm{mg}$ of crude venom protein, with an activity corresponding to $19.5 \%$ of the venom. The total activity significantly dwindled in the second stage (from 615.3 TRU to 124.4$)$, but the specific activity augmented gradually during the purification process $(148 \mathrm{U} / \mathrm{mg})$. The purification factor had also increased (4.1).

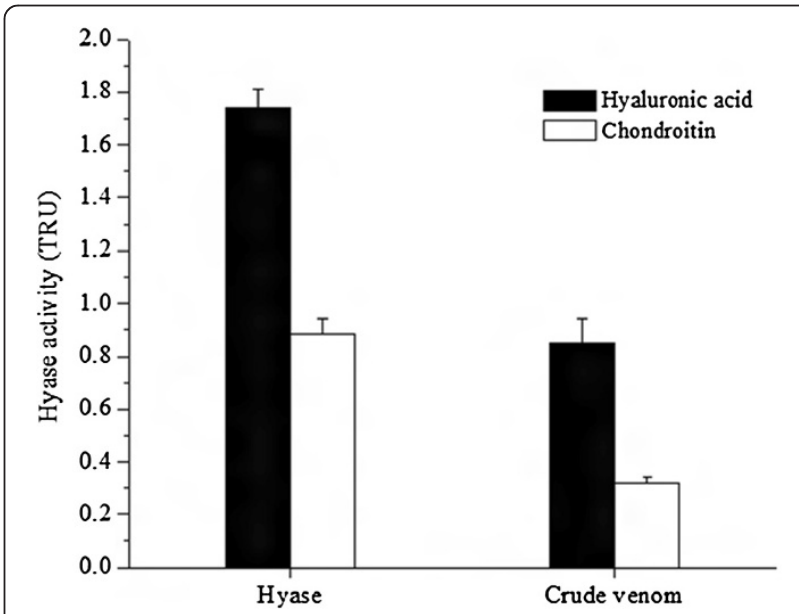

Figure 5 Enzymatic activity of $V$. dubius venom $(10 \mu \mathrm{g})$ and purified Hyase $(5 \mu \mathrm{g})$ on hyaluronic acid and chondroitin sulfate $\mathbf{A}$. The points represent mean $\pm \operatorname{SEM}(n=6)$. 


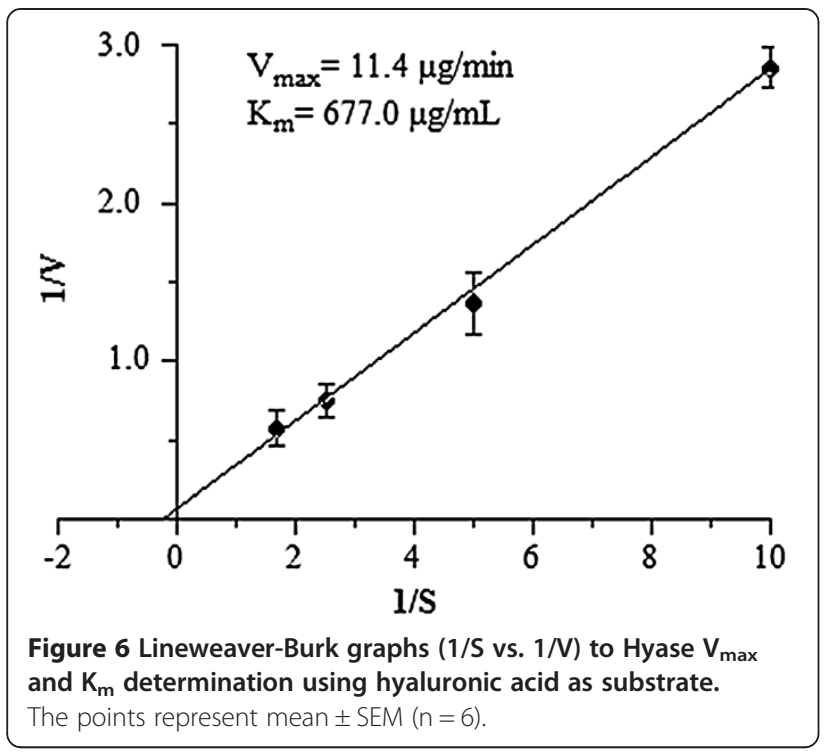

The investigation of the physicochemical characteristics of the purified enzyme showed maximum activity at $\mathrm{pH}$ between 4 and 5 and temperature from 35 and $40^{\circ} \mathrm{C}$. Lower activity was observed at $25^{\circ} \mathrm{C}$, decreasing gradually from $45^{\circ} \mathrm{C}$ onwards with total loss above $60^{\circ} \mathrm{C}$ (Figure 3 ).

Enzyme samples submitted to consecutive freeze-thaw cycles remained at maximum activity after the first three cycles ( 0,1 and 3 hours), with a slight decrease after six hours, remaining stable until 15 days. Otherwise, individual frozen aliquots maintained their activity until the seventh day, losing activity after 15 days of freezing (Figure 4).

The substrate specificity was evaluated in both purified enzyme and crude venom; it was observed that the Hyase has a higher specificity to hyaluronic acid, but a lower activity in the presence of chondroitin (Figure 5). The values obtained for $\mathrm{V}_{\max }$ and $\mathrm{K}_{\mathrm{m}}$ from $V$. dubiuspurified Hyase were $11.4 \mu \mathrm{g} / \mathrm{min}$ and $677.0 \mu \mathrm{g} / \mathrm{mL}$, respectively, as shown in Figure 6.
Antiophidic, antiscorpionic and antilonomic serum were inefficient at neutralizing the enzymatic activity (Figure 7A). The antiarachnid serum against enzyme and crude venom neutralized Hyase activity in a dosedependent manner (Figure 7B).

\section{Discussion}

The hyaluronidases (Hyases) that have been isolated from various sources and extensively characterized comprise a group of enzymes described as 4-hyaluronate glucanohydrolase (EC 3.2.1.35, hyaluronoglucosamidase), hyaluronate-3-glucanohydrolase (EC 3.2.1.36, hyaluronoglucuronidase) and hyaluronatelyase (EC 4.2.2.1) [27]. The presence of this enzyme has been described in several human tissues, animal venoms, pathogenic organisms and cancers. Animal venom Hyases are structurally similar to those from the acrosome membrane of sperm, which play a fundamental role in mammalian fertilization, and to Hyases Hyal-1 and Hyal-2 of mammalian lysosomes [28-30]. Thus, venom Hyases are attributed the scattering function by facilitating the spread of toxins through glucosamine glycan hydrolysis in connective tissue, thereby yielding systemic poisoning [31].

As expected, the venom of $P$. nigriventer presents higher Hyase activity than that of $V$. dubius, due to the former's abundant high-molecular-weight molecules, thus requiring a higher permeability to promote the dissemination of such components [1]. Moreover, the venom of $V$. dubius has few components of high molecular weight, but rather a predominance of low-weight molecules, such as peptides, thus less need of Hyase [20].

That molecular profile of $V$. dubius Hyase venom contributed to the enzyme purification process. In three chromatographic steps, we obtained the pure enzyme, while in the venoms from other animals-namely Tityus serrulatus, Buthus martensi, Apis mellifera, Vespula vulgaris, Synanceja horrida and Lonomia obliqua-more
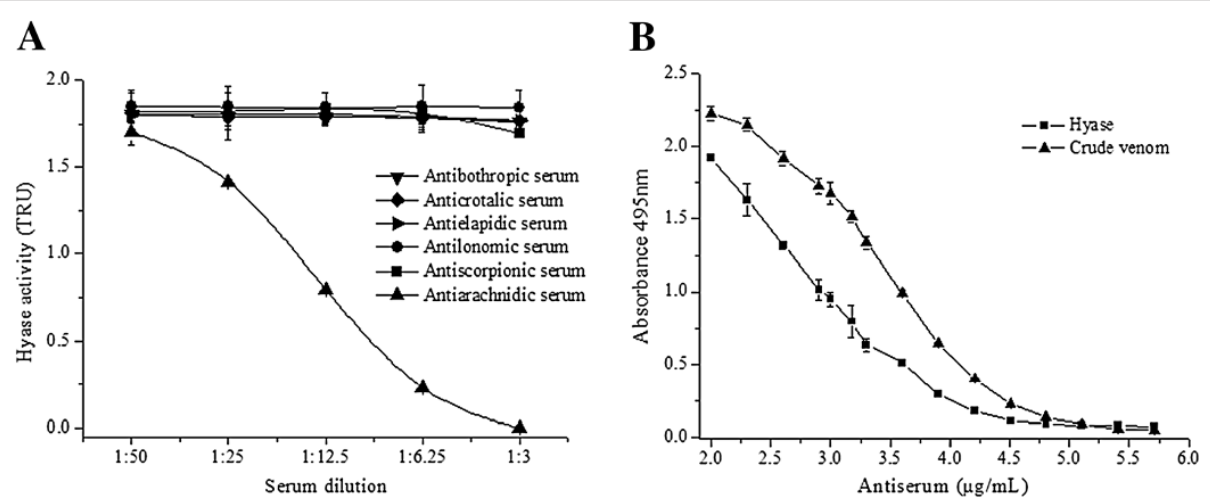

Figure 7 Immunological comparisons. (A) Dose-dependent neutralization of Hyase by anti-arachnidic serum. Antiscorpionic, antilonomic, antibothropic, anticrotalic and antielapidic sera were inefficient at neutralizing the enzymatic activity. (B) Reactivity of $V$. dubius venom (10 $\mu \mathrm{g})$ and purified Hyase $(5 \mu \mathrm{g})$ compared to anti-arachnidic serum on ELISA. The points represent mean \pm SEM $(n=6)$. 
chromatographic steps were necessary for Hyase purification $[11,27,28,32-34]$.

The enzyme yield (4.8\%) was considered low after purification, mainly because the enzyme is present at small concentrations in the total venom. Similar yields (4.9\%) can be obtained during the Hyase purification of the scorpion venom of Tityus serrulatus [27]. Otherwise, the purification from the venom of the scorpion Palamneus gravimanus, provided a higher yield, about 40\% [31].

The optimum working temperature of purified $V$. dubius Hyase is around $37^{\circ} \mathrm{C}$, which matches the physiological range of some of its largest prey, such as small rodents [35]. The enzyme loses its activity at $60^{\circ} \mathrm{C}$, perhaps due to losses in the molecular structure, thus compromising its activity. Same hyaluronidase temperature range can be found in the venom activity presented by Agkistrodon contortrix and Tityus serrulatus $[27,36]$.

The optimum $\mathrm{pH}$ found in $V$. dubius Hyase was between 4 and 5, the same described for Buthus martensi and Palamneus gravimanus enzymes [31,32]. In the Hyase of Hippasa partita, the best $\mathrm{pH}$ was observed to be 6 [37]. The finding of a $\mathrm{pH}$ between 4 and 5 can be explained by the preferential degradation of an acid substrate by the enzyme.

The $V$. dubius Hyase has a $\mathrm{K}_{\mathrm{m}}$ of $677.0 \mu \mathrm{g} / \mathrm{mL}$, indicating a comparatively low affinity of the substrate for the enzyme catalytic site, in contrast to the Hyases of $T$. serrulatus $(69.7 \mu \mathrm{g} / \mathrm{mL})$ and P. gravimanus $(47.61 \mu \mathrm{g} /$ $\mathrm{mL})$ scorpions, but similar to the stonefish Synanceja horrida $(709 \mu \mathrm{g} / \mathrm{mL})[27,31,33]$.

Testing the specificity of substrates, we observed that $V$. dubius Hyase exerts greater activity on hyaluronic acid compared to chondroitin, although still positive for the latter. The chondroitin test was positive for bovine hyaluronidase but negative for Hyases purified from the venoms of Hippasa partita and Agkistrodon contortrix $[36,37]$.

The neutralization of Hyase activity by antivenoms has not been widely studied. The experiments conducted in our laboratory showed that the venom Hyase of $V$. dubius was recognized by antiarachnid serum, in a dosedependent manner. The lack of influence of the antiscorpionic sera, obtained from Tytius venoms that are used for antiarachnid production, attest that the above neutralization is specifically due to antibodies raised against Loxosceles and Phoneutria sp., pooled for antivenom preparation against the latter. Neutralization also failed with antilonomic and antisnake sera, reinforcing the reaction specificity of $V$. dubius Hyase against spider antivenoms. This indicates that immunological identities may differ between the Hyase of arachnids and those of snakes and caterpillars. This immunological relationship has also been reported for several other enzymes and toxins of venoms [38].

\section{Conclusions}

Based on these findings, we conclude that the venom of $V$. dubius contains a Hyase with physicochemical and biochemical characteristics similar to other Hyases of venoms, although less potent. Nevertheless, the studied Hyase shares immunological features specifically with other spiders' enzymes, rather than those of caterpillars and snakes.

\section{Ethics committee approval}

The present study was approved by the Ethical Committee on Animal Research (UNICAMP) under the registration number 2167-1.

\section{Competing interests}

The authors declare that there are no competing interests.

\section{Authors' contributions}

This work was developed by RS, with the assistance of MLT in the experiments and was mentored by TAARS and SH. All authors read and approved the final manuscript.

\section{Acknowledgements}

The authors would like to thank the Center for Control of Zoonoses in Itu, São Paulo state, Brazil for providing the spiders for this study, José Ilton dos Santos for his support in the laboratory and CNPq and FAPESP for financial support and scholarships.

\section{Author details}

'Department of Physiological Sciences, Santa Casa de São Paulo Medical School, Rua Cesário Motta Jr., 61, Vila Buarque, CEP 01.221-020 São Paulo, SP, Brasil. ${ }^{2}$ Department of Pharmacology, School of Medical Sciences, Federal University of Campinas (UNICAMP), Campinas São Paulo state, Brazil.

\section{Received: 13 August 2013 Accepted: 31 January 2014}

Published: 4 February 2014

\section{References}

1. Rash LD, Hodgson WC: Pharmacology and biochemistry of spider venoms. Toxicon 2002, 40(3):225-254.

2. Kuhn-Nentwig L, Schaller J, Nentwig W: Purification of toxic peptides and the amino acid sequence of CSTX-1 from the multicomponent venom of Cupiennius salei (Areneae: Ctenidae). Toxicon 1994, 32(3):287-302.

3. Wright RP, Elgert KD, Campbell BJ, Barrett JT: Hyaluronidase and esterase activities of the venom of the poisonous brown recluse spider. Arch Biochem Biophys 1973, 159(1):415-426.

4. Young AR, Pincus SJ: Comparison of enzymatic activity from three species of necrotizing arachnids in Australia: Loxosceles rufescens, Badumma insignis and Lampona cylindrata. Toxicon 2001, 39(2-3):391-400.

5. Barbaro KC, Knysak I, Martins R, Hogan C, Winkel K: Enzymatic characterization, antigenic cross-reactivity and neutralization of dermonecrotic activity of five Loxosceles spider venoms of medical importance in the Americas. Toxicon 2005, 45(4):489-499.

6. da Silveira RB, Chaim OM, Mangili OC, Gremski W, Dietrich CP, Nader HB, Veiga SS: Hyaluronidases in Loxosceles intermedia (Brown spider) venom are endo- $\beta$ - $\mathrm{N}$-acetyl-d-hexosaminidases hydrolases. Toxicon 2007, 49(6):758-768.

7. Kaiser $E$ : The enzymatic activity of spider venom on the influence of sulfonated polysaccharides on the proteolytic and hyaluronic acid splitting activity of spider venom. Mem Inst Butantan 1953, 25(1):35-39.

8. Kaiser E: Enzymatic activity of spider venoms. In Venoms. Edited by Buckley EE, Porges N. Washington, DC: American Association for the Advancement of Science; 1956:91-93.

9. Schanbacher FL, Lee CK, Wilson IB, Howell DE, Odell GV: Purification and characterization of tarantula, Dugesiella hentzi (girard) venom hyaluronidase. Comp Biochem Physiol B 1973, 44(2):389-396. 
10. Lu G, Kochoumian L, King TP: Sequence identity and antigenic cross-reactivity of white face hornet venom allergen, also a hyaluronidase, with other proteins. J Bio/ Chem 1995, 270(9):4457-4465.

11. Kolarich D, Léonard R, Hemmer W, Altmann F: The N-glycans of yellow jacket venom hyaluronidases and the protein sequence of its major isoform in Vespula vulgaris. FEBS J 2005, 272(20):5182-5190.

12. Lucas S: Spiders in Brazil. Toxicon 1988, 26(9):759-772.

13. Lucas SM, Da Silva PI Jr, Bertani R, Costa Cardoso JL: Mygalomorph spider bites: a report on 91 cases in the state of São Paulo. Brazil Toxicon 1994, 32(10):1211-1215.

14. Isbister GK, Seymour JE, Gray MR, Raven RJ: Bites by spiders of the family Theraphosidae in humans and canines. Toxicon 2003, 41(4):519-524.

15. Escoubas $P$, Rash L: Tarantulas: eight-legged pharmacists and combinatorial chemists. Toxicon 2004, 43(5):555-574.

16. Windley MJ, Escoubas P, Valenzuela SM, Nicholson GM: A novel family of insect-selective peptide neurotoxins targeting insect BKCa channels isolated from the venom of the theraphosid spider: eucratoscelus constrictus. Mol Pharmacol 2011, 80(1):1-13

17. Edgerton $\mathrm{GB}$, Blumenthal KM, Hanck DA: Inhibition of the activation pathway of the T-type calcium channel CaV3.1 by ProTxll. Toxicon 2010, 56(4):624-636

18. Escoubas P: Molecular diversification in spider venoms: a web of combinatorial peptide libraries. Mol Divers 2006, 10(4):545-554.

19. Bertani R: Revision, cladistic analysis, and zoogeography of Vitalius, Nhandu, and Proshapalopus; with notes on other theraphosine genera (Araneae, Theraphosidae). Arq Zool S Paulo 2001, 36(3):266-350.

20. Rocha-e-Silva TAA, Sutti R, Hyslop S: Milking and partial characterization of venom from the Brazilian spider Vitalius dubius (Theraphosidae). Toxicon 2009, 53(1):153-161.

21. Rocha-E-Silva TAA, Rostelato-Ferreira S, Leite GB, da Silva PI, Jr HS, Rodrigues-Simioni L: VdTX-1, a reversible nicotinic receptor antagonist isolated from venom of the spider Vitalius dubius (Theraphosidae). Toxicon 2013, 70:135-141.

22. Di Ferrante N: Turbidimetric measurement of acid mucopolysaccharides and hyaluronidase activity. J Biol Chem 1956, 220(1):303-306.

23. Hames BD: One-dimensional polyacrylamide gel electrophoresis. In Gel Electrophoresis of Proteins: a Practical Approach. 2nd edition. Edited by Hames BD, Rickwood D. New York: Oxford University Press; 1990:1-147.

24. Cevallos MA, Navarro-Duque C, Varela-Julia M, Alagon AC: Molecular mass determination and assay of venom hyaluronidases by sodium dodecyl sulfate-polyacrylamide gel electrophoresis. Toxicon 1992, 30(8):925-930.

25. Reissig JL, Strominger JL, Leloir LF: A modified colorimetric method for the estimation of N-acetylamino sugars. J Biol Chem 1955, 217(2):959-966.

26. Segel I: Biochemical Calculations. New York: John Wiley \& Sons; 1972:454.

27. Pessini AC, Takao T, Cavalheiro EC, Vichnewski W, Sampaio SV, Giglio JR, Arantes EC: A hyaluronidase from Tityus serrulatus scorpion venom: isolation, characterization and inhibition by flavonoids. Toxicon 2001, 39(10):1495-1504.

28. Gmachl M, Kreil G: Bee venom hyaluronidase is homologous to a membrane protein of mammalian sperm. Proc Natl Acad Sci USA 1993, 90(8):3569-3573

29. Frost Gl, Csóka TB, Wong T, Stern R: Purification, cloning, and expression of human plasma hyaluronidase. Biochem Biophys Res Commun 1997 236(1):10-15.

30. Lepperdinger G, Stroble B, Kreil G: Hyal2, a human gene expressed in many cells, encodes a lysosomal hyaluronidase with a novel type of specificity. J Biol Chem 1998, 273(35):22466-22470.

31. Morey SS, Kiran KM, Gadag JR: Purification and properties of hyaluronidase from Palamneus gravimanus (Indian black scorpion) venom. Toxicon 2006, 47(2):188-195.

32. Feng L, Gao R, Gopalakrishnakone P: Isolation and characterization of a hyaluronidase from the venom of Chinese red scorpion Buthus martensi. Comp Biochem Physiol C Toxicol Pharmacol 2008, 148(3):250-257.

33. Poh $\mathrm{CH}$, Yuen $\mathrm{R}$, Chung MC, Khoo HE: Purification and partial characterization of hyaluronidase from stonefish (Synanceja horrida) venom. Comp Biochem Physiol B 1992, 101(1-2):159-163.

34. Da CB Gouveia Al, Da Silveira RB, Nader HB, Dietrich CP, Gremski W, Veiga SS: Identification and partial characterization of hyaluronidases in Lonomia obliqua venom. Toxicon 2005, 45(4):403-410.
35. Dias SC, Brescovit AD: Notes on the behavior of Pachistopelma rufonigrum Pocock (Araneae, Theraphosidae, Aviculariinae). Rev Bras Zool 2003, 20(1):13-17

36. Kudo K, Tu AT: Characterization of hyaluronidase isolated from Agkistrodon contortrix contortrix (Southern copperhead) venom. Arch Biochem Biophys 2001, 386(2):154-162.

37. Nagaraju S, Devaraja S, Kemparaju K: Purification and properties of hyaluronidase from Hippasa partita (funnel web spider) venom gland extract. Toxicon 2007, 50(3):383-393.

38. Elliott WB: Chemistry and immunology of reptilian venoms. In Biology of the reptilia: physiology B. 8th edition. Edited by Gans C, Gans K. London: Academic Press; 1978:163-436.

doi:10.1186/1678-9199-20-2

Cite this article as: Sutti et al:: Purification and characterization of a hyaluronidase from venom of the spider Vitalius dubius (Araneae, Theraphosidae). Journal of Venomous Animals and Toxins including Tropical Diseases 2014 20:2

\section{Submit your next manuscript to BioMed Central and take full advantage of:}

- Convenient online submission

- Thorough peer review

- No space constraints or color figure charges

- Immediate publication on acceptance

- Inclusion in PubMed, CAS, Scopus and Google Scholar

- Research which is freely available for redistribution 